\title{
The Canadian
}

Journal of Linguistics

La Revue canadienne

de Linguistique

SPRING/PRINTEMPS 1965-10:2,3 


\title{
Canadian Linguistic Association Association canadienne de Linguistique
}

\author{
OFFICERS/BUREAU \\ President/Président \\ Past President/ \\ Président sortant \\ Vice-President/Vice-Président \\ Secretary/Secrétaire \\ Treasurer/Trésorier \\ Members of the Executive/ \\ Membres du Conseil \\ Editor/Rédacteur \\ Associate Editor/ \\ Rédacteur adjoint

\section{Book Review Editor/ Rédacteur des Comptes rendus} \\ J.-P. VINay, Montréal \\ J. DARBELNET, Laval \\ College \\ W. F. MACKEY, Laval \\ R. J. GREGG, U.B.C. \\ J. W. Wevers, Toronto \\ Mme I. VACHON-SPILKA, \\ Montréal \\ M. RABOTIN, McGill
}

M. H. SCARGILL, Alberta (Calgary)

w. s. Avis, Royal Military College

H. R. WILSON, Royal Military

The canadian journal or linguistrcs is the official publication of the Association. Annual dues of four dollars, which include subscription to the Journal, are payable to the Treasurer. Available back issues may also be ordered from the Treasurer.

Manuscripts in English or French may be sent to the Editor, Prof. J. W. Wevers, Dept. of Near Eastern Studies, University of Toronto, Toronto 5, Canada. A Style Sheet should be secured from the Editor before the final manuscript is typed. Books for review should be sent to the Book Review Editor.

La ReVUe CANAdienne De linguistique est l'organe officiel de l'Association canadienne de Linguistique. Le montant de la cotisation, abonnement compris, est de quatre dollars et doit être versé au Trésorier. Les manuscrits et toute correspondance relative à la rédaction de la Revue doivent être envoyés au Rédacteur ou au Rédacteur adjoint. Les collaborateurs sont priés de demander le protocole de la Revue avant de rédiger la version définitive de leur manuscrit. Les livres pour recensions et les comptes rendus sont à envoyer au Rédacteur des comptes rendus.

Copyright 1965 by the Canadian Linguistic Association Published by the University of Toronto Press

The canadian Journal of LINGUistics continues the journal of THE CANADIAN LINGUISTIC ASSOCIATION.

La REVUE CANADIENNE DE LINGUISTIQUe fait suite à la REVUE DE L'ASSOCIATION CANADIENNE DE LINGUISTIQUE. 


\section{Contents}

THE CANADIAN JOURNAL OF LINGUISTICS, SPRING 1965, 10:2,3

\section{Sommaire}

LA REVUE CANADIENNE DE LINGUISTIQUE, PRINTEMPS 1965, 10:2,3

Editorial, 75

MARY R. HAAS, Is Kutenai related to Algonkian? 77

WILLIAM w. ELMENDORF, Some problems in the regrouping of Powell Units, 93

KENNETH HALE, On the use of informants in field-work, 108

JOE E. PIERCE, The field situation in Oregon: 1964,120

FANG-KUEI LI, Some problems in comparative Athapaskan, 129

C. F. voegelin and F. M. voegelin, Extinction of American Indian languages before and after contact periods, 135

M. SWADESH, Language universals and research efficiency in descriptive linguistics, 147

w. SUTTLES, Linguistic means for anthropological ends on the Northwest Coast, 156

MICHAEL E. KRAUSS, Eyak: a preliminary report, 167 